
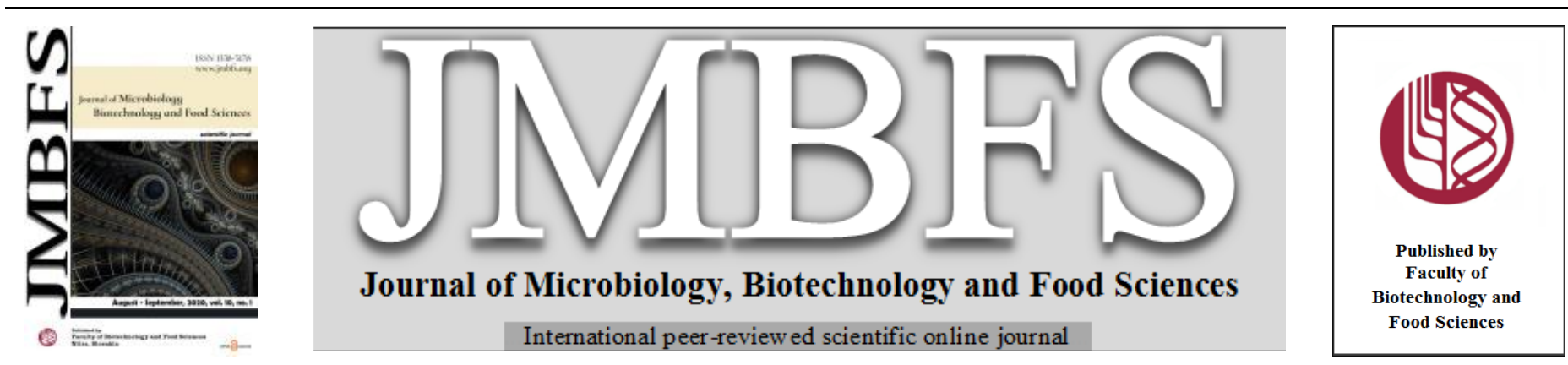

\title{
INFLUENCE OF COLD MACERATION TREATMENT ON AROMATIC AND SENSORY PROPERTIES OF VUGAVA WINE (Vitis vinifera L.)
}

\author{
Ana-Marija Jagatić Korenika*1, Tihomir Prusina ${ }^{2}$, Stipe Ivić ${ }^{3}$ \\ Address(es): Assist.Prof. Ana-Marija Jagatić Korenika, \\ ${ }^{1}$ University of Zagreb Faculty of Agriculture, Department of Viticulture and Enology, Svetošimunska cesta 25, 10000 Zagreb, Croatia. \\ ${ }^{2}$ University of Mostar Faculty of Agriculture and Food technology, Department of Viticulture and Enology, Biskupa Čule bb, 88000 Mostar, Bosnia and Herzegovina. \\ ${ }^{3}$ Institute for Adriatic Crops and Karst Reclamation, Department of Plant Sciences, Put Duilova 11,p.p. 288, 21000 Split, Croatia.
}

*Corresponding author: amjagatic@agr.hr

doi: 10.15414/jmbfs.2020.10.1.49-53

ARTICLE INFO

Received 9. 1.2020

Revised 4. 3. 2020

Accepted 11.3. 2020

Published 1. 8. 2020

Regular article

OPEN $\partial_{\text {ACCESS }}$

\begin{abstract}
In Croatian viticultural sub-region of Middle and South Dalmatia, several high-quality white wines, mainly using the native grape varieties, are being produced and one of them is Vugava from the island of Vis. The aim of this two-year study was to investigate the effect of cold maceration conditions on aromatic and sensory properties of Vugava wines in comparison to the control wine produced without maceration. The GC/MS method was used for the determination of higher alcohols, methanol, ethyl acetate, and acetaldehyde concentrations. Aromatic profile was obtained by odor activity values and sensory evaluation. The significant difference in concentrations of total higher alcohols and isoamyl alcohol was determined in both vintages unlike the differences in basic wine composition. There was no visible difference or significant increase of methanol and ethyl acetate concentration what is positive from the health and sensory point of view. Sensory evaluation of Vugava wines showed that treatment of cold maceration $\left(20 \mathrm{~h} / 10^{\circ} \mathrm{C}\right)$ resulted in increased complexity and better rated wine.
\end{abstract}

Keywords: aroma, cold maceration, higher alcohols, methanol, Vugava, white wine

\section{INTRODUCTION}

The pleasant and detectable aroma of wine is one of the main characteristic that can enable the differences and recognition among the vast array of wine styles produced throughout the world, especially when native, less known grapevine varieties are processed. The complex pool of volatile compounds that arise from grapes and metabolic activities of yeast and bacteria display a specific odor often defined with the terms "vinous" or "fermented" (de-la-Fuente-Blanco $\boldsymbol{e t}$ al., 2016). Beside the fact that the major volatile fractions of wine like alcohol, higher alcohols and their acetates, ethyl and acetate esters or acetaldehyde can be affected by the numerous conditions through the alcoholic fermentation, there are a lot of procedures, both in viticulture and in winemaking that can be used for producing wines with more highlighted aromatic profile. Pre-fermentative practices can determine the aromatic characteristics, especially in white wines production (Ribéreau Gayon et al., 2006). Pre-fermentative cold maceration (CM) is normally used in winemaking to enhance varietal character of white wines (Peinado et al., 2004) with considerable variations depending on the grape cultivar employed and experimental conditions (Darias-Martín et al., 2000; Selli et al., 2006). According to the different studies of maceration process affecting the aromatic profiles of white wines, contradictory results were presented. Studies performed with some aromatic varieties, showed benefits from skin contact due to a high amount of aroma precursors that can be extracted from their skins, while some others varieties had similar sensory profile to control wines or even less varietal characters, lower fruitiness and negative spicy attributes (Test et al., 1986; Selli et al., 2006; Cejudo-Bastante et al., 2011; Olejar et al., 2015). Short cold pre-fermentation maceration applied to Croatian native varieties Pošip and Škrlet had the significant influence on increasing of primary aroma compounds, i.e. terpenes and results obtained by Jagatić Korenika et al. (2018) suggested that practice that was used enhanced varietal typicity. In wines made from neutral grape varieties, the detectable aroma arises from combination of different volatile organic compounds and it determines wine character and quality (Sanchez Palomo et al., 2006). Higher (fusel) alcohols are the major constituents of the wine volatiles and according to de-la-FuenteBlanco et al. (2016) the scientific literature is not unanimous about the role played by higher alcohols in wine. Some researchers noted negatively effect of higher alcohols in younger and less expensive wines but not in premium wines, at similar levels (San-Juan et al., 2011). Research conducted by de-la-Fuente-
Blanco et al. (2016) suggested that the effect of higher alcohols extremely depends on the aromatic context i.e. when lacking specific aroma, they have buffering effect of wine aroma base. The same research confirms the sensory importance of isobutanol and isoamyl alcohol on wine aroma perception and a negative role of aliphatic higher alcohols on wine aroma quality regarding their ability to suppress fruity and woody notes. Some other authors noted high sensory impact of isoamyl alcohol and $\beta$ - phenyl ethanol (Capone et al., 2013; Gomez-Miguez et al., 2007).

Among many different aromatic compounds, esters have a significant effect on the fruity flavors in wine. Higher ester content is found in white wines compared to red wines, especially when a lower temperature is used during vinification (Clarke and Bakker, 2004). One of the most abundant and significant acetate esters is ethyl acetate that is only formed in small quantities by the yeast metabolism in the fermentation process, and any large concentrations are due to the presence of acetic acid bacteria during storage and barrel aging (Moreno and Peinado, 2012). Ethyl acetate can seriously impair the smell of wine, even below its perception threshold and long before the concentration of acetic acid in the wine causes it to become acetic (Moreno and Peinado, 2012). Acetaldehyde is the major carbonyl compound and metabolic intermediates found in wine (Schreier, 1979). Aldehydes contribute to flavor with aroma descriptors such as 'bruised apple' and 'nutty' but can also be a sign of wine oxidation (Swiegers et al., 2005). Numerous studies have shown that the administration of large concentrations of acetaldehyde can lead to a range of behavioral effects, notably those linked with symptoms of hangover and carcinogenic effect- the importance of screening acetaldehyde levels in alcoholic beverages has now been given special attention as a result of health concerns (Salaspuro, 2011). Methanol is formed by enzymatic hydrolysis of pectin present mostly in skins and other grape solids. More methanol is produced when must is fermented on grape skins (Radeka et al., 2012) hence there are generally higher levels in red than in rosé or white wines. Methanol is a toxic chemical but even wine containing the maximum allowable methanol content by regulation never has a high enough concentration to give rise to public health concerns. It seems possible that at one time they were intended to serve as an index of appropriate fruit handling in harvest and subsequent processing (FIVS, 2016).

Vugava is a near threatened, native white variety from the Coastal region of Croatia with a high reputation during history. Once it was used as a table grape, and its dessert wines made from grapes dried in the sun were especially 
appreciated. As a disadvantage with this variety, premature ripening may be counted in some years, leading to problems with harvesting and fermentation due to high temperatures. Vugava has extremely high qualitative potential, it regularly accumulates high sugar, and because of its intense distinctive and pleasant varietal aroma, it produces famous white wines with a pronounced fruity aroma (Maletić et al., 2015). In order to demonstrate its high potential, it is important to apply modern technological solutions in wine-making, above all in order to preserve the aroma and freshness of wine. Due to the deficiency of information about the effect of technology on the aroma profile of Vugava wine, the aim of this two-year study was to apply different lengths of cold maceration to pomace and analyze the volatile compounds and sensory properties of produced wines in comparison to standard wine.

\section{MATERIALS AND METHOD}

\section{Grapes and winemaking}

The experiment was performed during vintages 2006 and 2007 with grapes of Vugava variety (Vitis vinifera L.) grown in viticultural subregion of Middle and South Dalmatia, wine growing hill Island of Vis, with a typical Mediterranean climate. Specific vineyard was situated in wine growing locality Radovinka on the southwestern part of the island, owned by cooperative "Podšpilje". Healthy grapes were manually harvested and transported to experimental wine cellar of Institute for Adriatic Crops and Karst Reclamation in Split, in $20 \mathrm{~kg}$-plastic cases. The degree of ripeness was monitored by standard chemical analysis (sugars, total acidity and $\mathrm{pH}$ ). All the vinifications were done with randomly chosen 3 cases of grapes. Three treatments were studied: (i) A- control vinification without cold maceration, (ii) B-cold maceration 10 hours on $10{ }^{\circ} \mathrm{C}$, alcoholic fermentation on $18{ }^{\circ} \mathrm{C}$, (iii) C- cold maceration 20 hours on $10{ }^{\circ} \mathrm{C}$, alcoholic fermentation on $18{ }^{\circ} \mathrm{C}$. After cooling of pomace in refrigeration tanks, free-run juices of the individual treatments were sulphited with 5 g.hL ${ }^{-1} 5 \%$ $\mathrm{H}_{2} \mathrm{SO}_{3}$ and sedimented for 24 hours. Alcoholic fermentation of the precipitated musts of all treatments was carried out in triplicates with selected wine yeasts Saccharomyces cerevisiae Lalvin ICV D47 (Lallemand SA, Montreal, Canada). During the fermentation process, the breakdown of sugar was monitored daily using a refractometer together with measuring the must temperature. After the completion of alcoholic fermentation, wines were racked-off and sulphited with $15 \mathrm{~g} . \mathrm{hL}^{-1}$. Wines were stored for 3 months at temperatures not exceeding $20^{\circ} \mathrm{C}$, filtered and samples were taken for analyses and sensory evaluation.

\section{Analyses of volatile aroma compounds}

Aroma compounds from wines were extracted by solid phase micro extraction (SPME) (Arthur and Pawliszyn, 1990) and analyzed using an Agilent Gas Chromatograph 6890 (USA) series system coupled with an Agilent 5973 Inert mass-selective detector and an automatic injector (7683B Series Injector). Volatile compounds were identified by using the Enhanced Chemstation software (Agilent Technologies, USA). Aroma compounds were identified by comparing the peak retention times against those of referent standards and matching the mass spectra against Nist05 mass library (Wiley \& Sons, USA). All the analyzes were performed in the Laboratory for grape, must and wine at University of Zagreb Faculty of Agriculture, Department of Viticulture and Enology.

\section{Odor activity values}

Odor activity values (OAV) of volatile aroma compounds were calculated as the quotients of their concentration (c) and the corresponding odor perception threshold (OPT) reported in the literature (Sáenz-Navajas et al., 2015). It estimates the contribution of individual compound to the aroma of wine and yields aroma profile together with all quantified components (Peinado et al., 2004). Each volatile compound has been associated with odor descriptors reported in literature.

\section{Sensory evaluation of wine}

The sensory properties of the wines were evaluated using the 100 points method and the ranking method with the participation of 10 certificated wine evaluators. The evaluators had to rank the wines according to aroma and overall impression of quality by method proposed by Amerine and Roessler (1976)

\section{Statistical analysis}

One-way analysis of variance (ANOVA) was performed on the data collected using the Statistica, ver. 7.1. (StatSoft, Inc., Tulsa, USA). The differences between the mean values $(n=3)$ of the dependent variables were determined by the Least Significant Difference (LSD) at the level of significance of $p<0.05$ and $\mathrm{p}<0.01$. A multivariate analysis was performed by Principal Component Analysis (PCA) to identify the differences between wines and to identify differences in the maceration process.

\section{RESULTS AND DISCUSSION}

\section{Alcoholic fermentation dynamics}

Average data of must from vintage 2006 were $94^{\circ} \mathrm{Oe}\left(206\right.$ g.L.-1), 6.9 g.L $\mathrm{L}^{-1}$ titratable acidity (as tartaric acid) and $\mathrm{pH}$ 3.47. In vintage 2007 grapes were more ripe with $106{ }^{\circ} \mathrm{Oe}\left(236\right.$ g.L $\left.\mathrm{L}^{-1}\right), 5.3$ g.L $\mathrm{L}^{-1}$ titratable acidity and $\mathrm{pH}$ 3.39. The breakdown of sugars and the dynamics of fermentations are shown in Fig. 1a/b. Regarding the higher concentration of sugars in Vugava must 2007, the alcoholic fermentation lasted longer in all studied treatments in comparison to vintage 2006. Application of cold maceration affected fermentation in the same way in both vintages by decreasing the fermentation rate in the following order $\mathrm{A}>\mathrm{B}>$ C. Application of $\mathrm{CM}$ at low temperature $\left(10{ }^{\circ} \mathrm{C}\right)$ and with $\mathrm{SO}_{2}$ addition influenced the start and duration of fermentation. The difference in completion of fermentation between A and C treatment was four days in 2006, and six days in 2007. There was no difference in CM effect on completion of fermentation to dryness in both years.

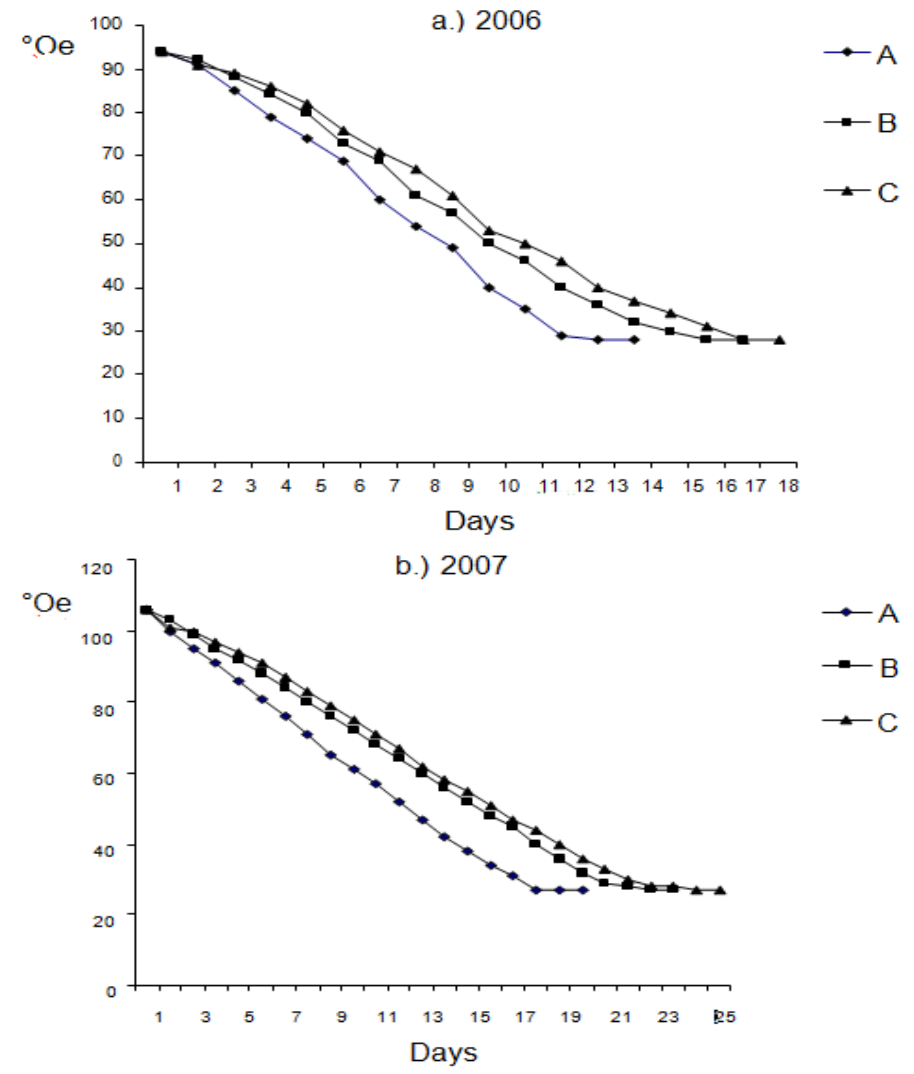

Figure 1a/b Effect of cold maceration on fermentation performance in Vugava wines, 2006 and 2007

\section{Wine composition}

According to obtained results there was no significant difference for any basic quality parameter (Fig. 3) that is in accordance with research published by Peinado et al. (2004) and different from previous studies (Cabaroglu et al., 1997; Darias-Martin et al., 2000). Methanol deriving from the demethylation of pectin was influenced by CM only in Vugava 2006 where the concentration significantly decreased (Table 1) what is in opposite from results published by Darias-Martin et al. (2000) and similar to study by Bavčar et al., (2011).

Methanol levels ranged from the highest found in control wine 2006, to the lowest in control wine 2007, both within range typical for white wines (40- 120 $\mathrm{mg} . \mathrm{L}^{-1}$ ) according to Sponholz (1989) and under the OIV limitation for methanol content in white wine $\left(250 \mathrm{mg} . \mathrm{L}^{-1}\right)$. CM wines in both years did not exhibit an increased level of acetaldehyde. The range of values measured in all wines were under the detectable value of $80 \mathrm{~g} . \mathrm{L}^{-1}$ for white wines (McCloskey and Mahaney, 1981). At low level in wine acetaldehyde gives a pleasant, fruity aroma but at higher level, it nevertheless imparts an irritating odor that has been described as a green, grassy, nutty or rotten apple-like aroma (Waterhouse et al. 2016). 
Table 1 Concentration, odor perception thresholds (OPT), odor descriptors and odor activity values (OAV) for methanol, acetaldehyde, ethyl-acetate and higher alcohols (mg.L $\left.\mathrm{L}^{-1}\right)$ in Vugava wines 2006 and 2007.

\begin{tabular}{|c|c|c|c|c|c|c|}
\hline Compound & OPT $^{\prime}$ & Odor descriptors" & Vintage & $\mathrm{A}$ & B & $\mathrm{C}$ \\
\hline \multirow[t]{2}{*}{ Methanol } & \multirow[t]{2}{*}{668} & \multirow[t]{2}{*}{ cabbage } & 2006 & $103.6^{\mathrm{a}}$ & $76.4^{\mathrm{c}}$ & $82.6^{b}$ \\
\hline & & & 2007 & 58.5 & 59.7 & 64.1 \\
\hline \multirow[t]{2}{*}{ Acetaldehyde } & \multirow[t]{2}{*}{80} & \multirow{2}{*}{$\begin{array}{l}\text { pungent, } \\
\text { apple }\end{array}$} & 2006 & 50.2 & 51.5 & 53.4 \\
\hline & & & 2007 & 43.8 & 43.1 & 42.8 \\
\hline \multirow[t]{2}{*}{ Ethyl acetate } & \multirow[t]{2}{*}{7.5} & \multirow{2}{*}{$\begin{array}{l}\text { fruity, pineapple, } \\
\text { nail polish remover }\end{array}$} & 2006 & $20.5(2.73)^{*}$ & $26.0(3.47)^{*}$ & $27.7(4.23)^{*}$ \\
\hline & & & 2007 & $54.9^{\mathrm{a}}(7.32)^{*}$ & $51.6^{\mathrm{a}}(6.88)^{*}$ & $44.0^{\mathrm{b}}(5.87)^{*}$ \\
\hline \multicolumn{7}{|c|}{ Higher alcohols (HA) } \\
\hline \multirow[t]{2}{*}{ 1-Propanol } & \multirow[t]{2}{*}{9} & \multirow[t]{2}{*}{ alcohol, ripe fruit, sweet } & 2006 & $37.74^{\mathrm{b}}(4.19)^{*}$ & $47.31^{\mathrm{a}}(5.26)^{*}$ & $48.22^{\mathrm{a}}(5,36)^{*}$ \\
\hline & & & 2007 & $41.52(4.62)^{*}$ & $40.05(4.45)^{*}$ & $39.00(4.33)^{*}$ \\
\hline \multirow[t]{2}{*}{ Isobutanol } & \multirow[t]{2}{*}{40} & \multirow{2}{*}{$\begin{array}{l}\text { alcohol, solvent green, } \\
\text { bitter }\end{array}$} & 2006 & $39.97^{\mathrm{c}}$ & $46.83^{\mathrm{b}}(1.17)^{*}$ & $57.75^{\mathrm{a}}(1.44)^{*}$ \\
\hline & & & 2007 & 30.10 & 31.25 & 33.50 \\
\hline \multirow[t]{2}{*}{ 1-Butanol } & \multirow[t]{2}{*}{150} & \multirow{2}{*}{$\begin{array}{l}\text { medicinal, } \\
\text { whiskey }\end{array}$} & 2006 & 0.97 & 1.20 & n.d. \\
\hline & & & 2007 & 1.67 & 1.58 & 2.12 \\
\hline \multirow[t]{2}{*}{ Isoamyl alcohol } & \multirow[t]{2}{*}{60} & \multirow[t]{2}{*}{ fruity, banana, solvent } & 2006 & $292.00^{\mathrm{a}}(4.86)^{*}$ & $182.72^{\mathrm{b}}(3.05)^{*}$ & $190.72^{\mathrm{b}}(3.18)^{*}$ \\
\hline & & & 2007 & $268.41^{\mathrm{a}}(4.47)^{*}$ & $285.53^{\mathrm{b}}(4.76)^{*}$ & $282.31^{\mathrm{ab}}(4.71)^{*}$ \\
\hline \multirow[t]{2}{*}{ 2-Butanol } & \multirow[t]{2}{*}{ n.a. } & \multirow[t]{2}{*}{ apricot, oily, sweet, wine } & 2006 & n.d. & $0.02^{\mathrm{a}}$ & n.d. \\
\hline & & & 2007 & $6.38^{\mathrm{a}}$ & n.d. & n.d. \\
\hline \multirow[t]{2}{*}{ Total HA } & & & 2006 & $374.00^{\mathrm{a}}$ & $278.12^{\mathrm{c}}$ & $296.82^{b}$ \\
\hline & & & 2007 & 348.12 & 358.44 & 356.94 \\
\hline
\end{tabular}

Legend: All data present mean value $(\mathrm{n}=3) ; \mathrm{A}=$ control, $\mathrm{B}=$ cold maceration $10^{\circ} \mathrm{C} / 10 \mathrm{~h}, \mathrm{C}=$ cold maceration $10^{\circ} \mathrm{C} / 20 \mathrm{~h}$; n.a. - not available; Different lower case superscript letters represent statistically significant differences between means at $\mathrm{p} \leq 0.05$; OAV- odor activity values, * OAV > 1 (values in brackets); ' , " OPT and OD reported in: Peinado et al. (2004), Gómez-Míguez et al. (2007), Güth (1997), Swiegers et al., (2005).

The concentration of individual higher alcohols (HA) is shown in Table 1. The most abundant compound was isoamyl alcohol, what is in accordance with results for other Croatian white varieties (Jagatić Korenika et al., 2018). The results obtained show the significant effect of $\mathrm{CM}$ on 1-propanol, isoamyl alcohol, isobutanol and total HA concentration. In both years no repeatability was observed in CM effect on total or individual concentrations of HAs, though the fermentation was conducted under same conditions. An explanation can be hidden in the significant influence of must turbidity on the synthesis of higher alcohols (Postel et al., 1972; Dittrich, 1987; Herjavec and Prusina, 2008) since Vugava must 2007 was more turbid than the must from vintage 2006. The total amount of HAs after fermentation never exceeded $400 \mathrm{mg} . \mathrm{L}^{-1}$ what can adversely affect the quality of the wine (Rapp and Mandrey, 1986). The significan influence of $\mathrm{CM}$ on the increase of total HAs in previous research was explained by enrichment of the amino acids involved in the formation of higher alcohols via the Ehrlich mechanism (Ramey et al., 1986; Falque and Fernandez, 1996; Cabaroglu et al., 1997; Darias-Martin et al., 2000; Selli et al., 2006a). There are also studies with conflicting results (Palomo et al., 2006; Selli et al., 2006; Palomo et al., 2007) where a decrease in the concentration of total HAs have been observed, what was explained by blocking the Ehrlich mechanism, the major biosynthetic pathway of higher alcohols, due to increased levels of nitrogen compounds in the must after the maceration process (Rapp and Versini, 1995). Compared to the total concentration of HAs, the content of isoamyl alcohol in Vugava wines accounted for $70 \%$ in 2006, and $77 \%$ in 2007 . Usseglio-Tomasset (1995) pointed out that isoamyl alcohol is constantly present in wine, and that is most represented in relation to other higher alcohols with relative content about $73.6 \%$ of total higher alcohols. In 2007 wines, isoamyl alcohol concentrations were much closer to the upper limit of $300 \mathrm{mg} . \mathrm{L}^{-1}$, which are reported as limiting for white wine quality. The concentration of 1 - propanol in Vugava wines were within the ranges previous reported by Amerine and Ough (1980) and Herjavec (1989). Usseglio- Tomasset (1995) stated that in wine compared to the total content of higher alcohols, about $5 \%$ is 1-propanol. In Vugava wines from both harvests, 1-propanol accounted for about $8 \%$ of the total concentration of higher alcohols.

Concentration of ethyl acetate differed regarding the vintage. According to Ribéreau-Gayon et al. (2006) this ester at low concentrations (50-80 mg. $\left.\mathrm{L}^{-1}\right)$ has a significant positive effect on wine quality. More studies confirmed that concentrations less than $50 \mathrm{mg} \cdot \mathrm{L}^{-1}$, contribute to the complexity of the odor, while above $150 \mathrm{mg} . \mathrm{L}^{-1}$ give negative aromas reminiscent of nail polish, glue and vinegar (Ough and Amerine, 1980; Amerine and Roessler, 1983). There were statistically significant differences among treatments during harvest 2007, where $\mathrm{CM}$ resulted in decreasing of ethyl acetate concentration what is in accordance with Bavčar et al. (2011) and partly with Peinado et al. (2004).

Factors PC1 and PC2 described 99.58\% interdependence of all observed parameters for Vugava wines 2006 and 2007 (Fig. 2). Parameters that differ significantly or are similar for the harvests were also visible. Thus, the four parameters observed differ significantly depending on the year of harvest: isoamyl alcohol, isobutanol, 1-propanol, and total higher alcohols. The red rectangle in Fig. 2(b) is highlighted and its magnified image represents Fig. 3 which points to the similarities of wines from two different harvests in alcohol, total extract, reducing sugars, total acidity, volatile acids, ash, $\mathrm{pH}, 2$-butanol and 1- butanol.

(a)
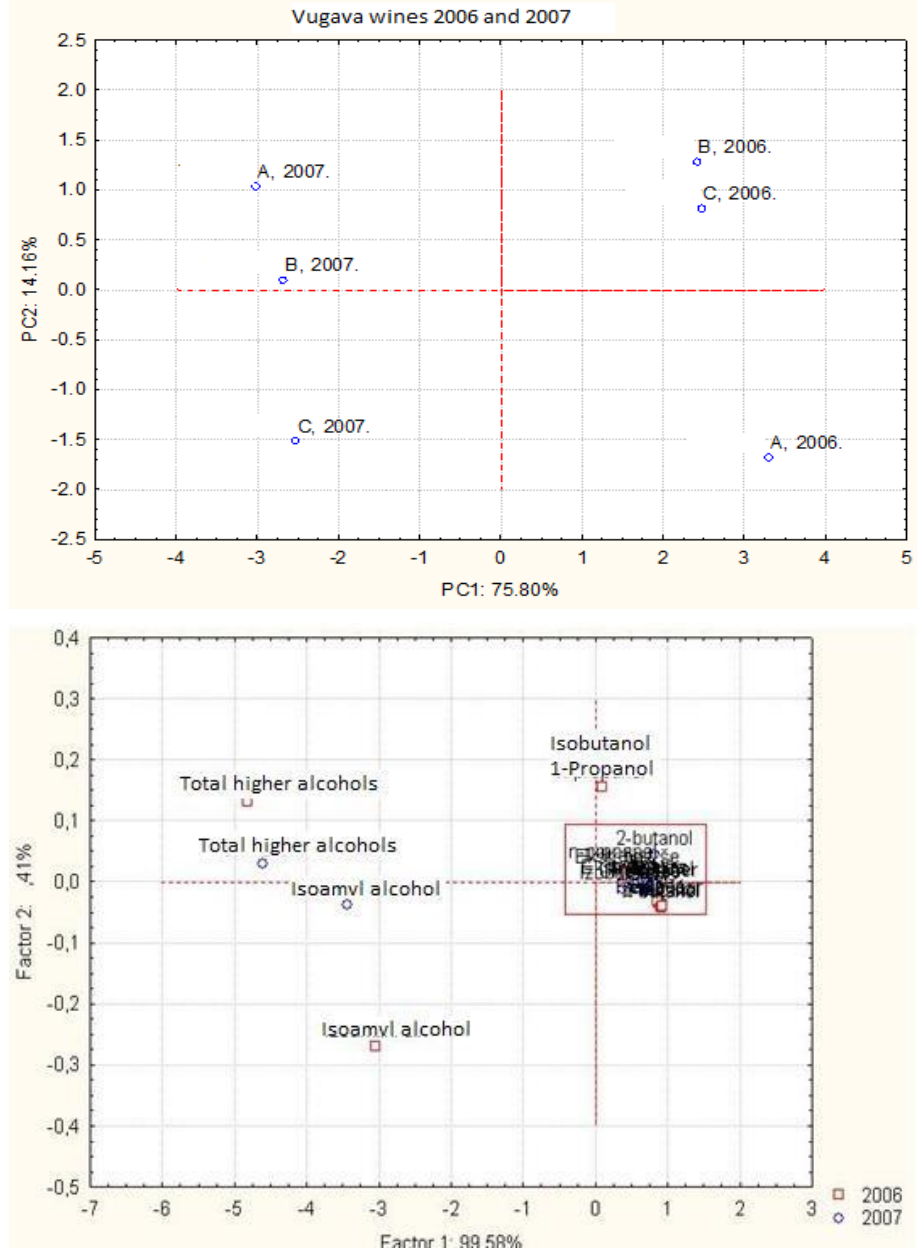

Figure 2 Score plot (a) and loading plot (b) of the first and second principa components after the PC analysis of chemical compounds in Vugava wines 2006 and 2007 


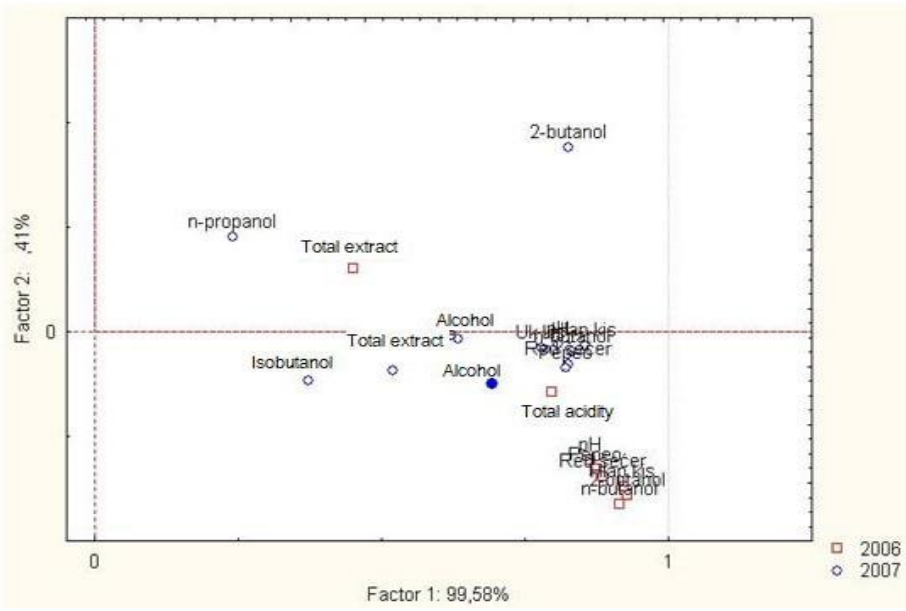

Figure 3 A separate section of the PCA diagram of the observed parameters for Vugava wine 2006 and 2007

\section{Odor activity values}

Table 1 shows odor descriptors and odor activity values (OAV) for each volatile compound of Vugava wines. OAVs > 1 are considered as active odorants, although some studies have reported the relevance of compounds present at OAV $>0.2$ to the overall aroma (Gómez-Míguez et al., 2007a). Among higher alcohols only 1- propanol, isoamyl alcohol, and isobutanol (B, C 2007) were detected above odor perception thresholds, with OAV $>1$, together with ethyl acetate. The most abundant alcohol detected in wines, isoamyl alcohol at optimal concentrations brings the typical banana and pear-like aroma (Swiegers $\boldsymbol{e t}$ al., 2005; Samappito and Butkhup, 2010) while excessive concentrations cause the nail polish odor of wines. One of the most significant aliphatic higher alcohols with the smell of ripe fruit is 1-propanol which had the highest OAV in $\mathrm{CM}$ wines from 2006. Cold maceration affected and OAV for isobutanol in the same vintage, known for alcohol, wine-like or solvent odor.

\section{Sensory evaluation}

In order to compare the chemical composition and odor activity values sensory evaluation was performed for vintage 2007. Control and CM wines were compared and best wine was selected by 10 certificated evaluators. Using the 100-points method the highest evaluated wine was Vugava wine (C) produced by $\mathrm{CM} 10{ }^{\circ} \mathrm{C} / 20 \mathrm{~h}$ (Table 2). The ranking method was used to rank the wines according to the overall impression of quality and aroma quality of Vugava wines. Differences were found between wines of different treatments, both by the aroma and overall quality. The results presented here indicate that the evaluators rated the wine obtained by $\mathrm{CM} 10{ }^{\circ} \mathrm{C} / 20 \mathrm{~h}(\mathrm{C})$ as the best due to the overall impression of quality. The wine $\mathrm{C}$ was characterized by a distinctive aroma and a more intense, full and rounded taste. The wine B and A were ranked as the second without statistical significant difference for the overall quality and aromatic characteristics. This results are similar to those for Žilavka wine (Herjavec and Prusina, 2008), where maceration period of 20 hours resulted with better quality compared to the wines obtained by maceration of 10 hours at the same temperature. Maceration process resulted in a more distinctive aroma of the Traminer variety (Herjavec and Majdak, 2002) and Malvasia Istriana (Radeka, 2008) as well.

Table 2 Sensory evaluation of Vugava wine 2007 by 100-points and ranking method

\begin{tabular}{ccccc}
\hline Sensory method & & $\mathrm{A}$ & $\mathrm{B}$ & $\mathrm{C}$ \\
\hline 100 points & & 79.0 & 80.0 & 81.7 \\
\hline \multirow{2}{*}{ Ranking } & Aroma quality & $7^{\mathrm{a}}$ & $11^{\mathrm{b}}$ & $12^{\mathrm{b}}$ \\
\cline { 2 - 5 } & Overall quality & $6^{\mathrm{Aa}}$ & $11^{\mathrm{Bb}}$ & $13^{\mathrm{Bb}}$ \\
\hline
\end{tabular}

Legend: Values for ranking method outside the range 8-16 are significant at $\mathrm{p} \leq 0.05$, and outside the range $7-17$ at $\mathrm{p} \leq 0.01$.

\section{CONCLUSION}

The present two-year research demonstrated how pre-fermentative cold maceration $(\mathrm{CM})$ technique significantly affected the aromatic and sensory properties of Vugava wine. Application of $\mathrm{CM}$ affected fermentation by decreasing the fermentation rate. Dry white wines obtained by treatments did not show significant difference in basic chemical composition in comparison to control wine and with respect to higher alcohols it resulted with counter effect. The most abundant volatile compound was isoamyl alcohol with concentration above its threshold together with 1-propanol and isobutanol. The CM showed an opposite effect on methanol and ethyl acetate concentration by no visible difference or significant decrease what is positive from the health and sensory point of view. Concentrations of total higher alcohols, acetaldehyde and ethyl acetate were within the range of values with positive contribution to the complexity of the odor mostly through fruity aroma nuances. Results showed positive effect of CM technique in production of Vugava wine with distinctive aroma of the variety, with a pronounced fruity aroma, and more intense and rounded flavor. The results of this research should contribute to a better valorization of the aromatic potential of Vugava variety, which will assist in practical production of high quality autochthonous wine with highly pronounced cultivar characteristics.

\section{REFERENCES}

Amerine, M.A., Ough, (1980). Methods for Analysis of musts and wines, New York: John Wiley \& Sons

Amerine, M.A., Roessler, E.B. (1976). Wines and Their sensory evaluation, San Francisco: W. H. Freeman and Co.

Amerine, M.A., Roessler, E.B. (1983). Wines, Their Sensory Evaluation, New York: Freeman.

Arthur C.L., Pawliszyn J. (1990). Solid phase microextraction with thermal desorption using fused silica optical fibers, Anal. Chem., 62(19), 2145-2148. http://dx.doi.org/10.1021/ac00218a019

Bavčar, D., Baša Češnik, H., Vanzo, A., Gašperlin, L., Košmerl, T. (2011) Impact of Alternative Skin Contact Procedures on the Aroma Composition of White Wine, S. Afr. J. Enol. Vitic., 32(2), 190-203.

Cabaroglu T., Canbas A., Baumes R., Bayonove C., Lepoutre J.P. and Günata Z. (1997). Aroma Composition of a White Wine of Vitis vinifera L. cv. Emir as Affected by Skin Contact, Journal of Food Science, 62(4), 680-683. http://dx.doi.org/10.1111/j.1365-2621.1997.tb15434.x

Capone, S., Tufariello, M., Siciliano, P. (2013). Analytical characterisation of Negroamaro red wines by "Aroma Wheels". Food Chemistry, 141(3), 2906- 15. https://doi.org/10.1016/j.foodchem.2013.05.105

Cejudo-Bastante M.J., Castro-Vázquez L., Hermosín-Gutiérrez I., Pérez-Coello M.S. (2011). Combined effects of prefermentative skin maceration and oxygen addition of must on color-related phenolics, volatile composition, and sensory characteristics of Airén white wine. Journal of Agriculture and Food Chemistry, 59, 12171-12182. http://dx.doi.org/10.1021/jf202679y

Clarke, R. J., Bakker, J. (2004). Wine flavour chemistry. Oxford, UK: Blackwell Publishing Ltd., 324.

Darias-Martín J.J., Rodríguez O., Díaz E., Lamuela-Raventós R.M. (2000). Effect of skin contact on the antioxidant phenolics in white wine. Food Chemistry, 71, 483-487. http://dx.doi.org/10.1016/S0308-8146(00)00177-1

de-la-Fuente-Blanco, A., Sáenz-Navajas, M., Ferreira, V. (2016). On the effects of higher alcohols on red wine aroma. Food Chemistry, 210, 107-14 http://dx.doi.org/10.1016/j.foodchem.2016.04.021

Dittrich, H.H. (1987). Mikrobiologie des Weines, Stuttgart: Ulmer

Falqué, E., Fernández, E. (1996). Effects of different skin contact times on Treixadura wine composition. American Journal of Enology and Viticulture, 47, 309-311.

FIVS (2016). Methanol in Wine. Available at: htpps://www.fivs.org. [Accessed 13 August 2019]

Gómez-Míguez, M. J., González-Miret, M. L., Hernanz, D., Angeles Fernández, M., Vicario, I. M., Heredia, F. J. (2007). Effects of prefermentative skin contact conditions on colour and phenolic content of white wines. J. Food Eng., 78, 238245. http://dx.doi.org/10.1016/j.jfoodeng.2005.09.021

Gómez-Míguez M.J., Gómez-Míguez M., Vicario I.M., Heredia F.J. (2007a) Assessment of colour and aroma in white wines vinifications: Effects of grape maturity and soil type. Journal of Food Engineering, 79, 758-764. http://dx.doi.org/10.1016/j.jfoodeng.2006.02.038

Güth, H. (1997). Quantitation and sensory studies of character impact odorants on different white wine varieties. Journal of Agricultural and Food Chemistry, 45(8), 3027-3032.

Herjavec, S. (1989). Utjecaj strojne berbe grožđa na kakvoću bijelih vina, Doktorska disertacija, Sveučilište u Zagrebu, Agronomski fakultet.

Herjavec S., Majdak A. (2002). The influence of maceration on the composition of some volatile compounds and sensory properties of Traminer wines, Agriculturae Conspectus Scientificus, 67(1), 11-17.

Herjavec, S., Prusina T. (2008). Influence of Fermentation Temperature on the Quality of 'Žilavka' Wines. Agriculturae conspectus scintificus, 73(2), 127- 130. Jagatić Korenika, AM., Maslov Bandić, L., Jakobović, S., Palčić, I., Jeromel, A. (2018). Comparative study of aromatic and polyphenolic profiles of Croatian white wines produced by cold maceration. Czech Journal of Food Sciences, 36(6), 459-469. http://dx.doi.org/10.17221/448/2017-CJFS

Maletić, E., Karoglan Kontić, J., Pejić, I., Preiner, D., Zdunić, G., Bubola, M., Stupić, D., Andabaka, Ž., Marković, Z., Šimon, S. et al.(2015). Zelena knjiga:hrvatske izvorne sorte vinove loze, Zagreb: Državni zavod za zaštitu prirode.

McCloskey, L.P., Mahaney, P. (1981). An enzymatic assay for acetaldehyde in grape juice and wine. Am. J. Enol. Vitic., 32, 159-162. 
Moreno, J., Peinado R. (2012). Enological Chemistry, Elsevier Inc. https://doi.org/10.1016/C2011-0-69661-9

Olejar K.J., Fedrizzi B., Kilmartin P.A. (2015). Influence of harvesting technique and maceration process on aroma and phenolic attributes of Sauvignon blanc
wine.
Food
Chemistry,
183
181-189.

http://dx.doi.org/10.1016/j.foodchem.2015.03.040

Palomo, E.S., González Viñas, M A., Díaz-Maroto, M.C., Soriano Perez, A., Perez- Coello (2007). Aroma potential of Albillo wines and effect of skin-contact treatment, Food Chemistry, 103, 631-640 http://dx.doi.org/10.1016/j.foodchem.2006.08.033

Peinado R.A., Moreno J., Bueno J.E., Moreno J.A., Mauricio J.C. (2004). Comparative study of aromatic compounds in two young white wines subjected to pre- fermentative cryomaceration. Food Chemistry, 84, 585-590. http://dx.doi.org/10.1016/S0308-8146(03)00282-6

Postel, W., Drawert, F., Adam, L. (1972). Gaschromatografische bestimmung der inhaltstoffe von garungsgetranken, III Fluchtige inhaltstoffe des Weines, Chem. Microbiol. Technol. Lebensmitt.,1, 224-235.

Radeka, S., Herjavec, S., Peršurić, Đ., Lukić, I., Sladonja, B. (2008). Effect of different maceration treatments on free and bound varietal aroma compounds in wine of Vitis vinifera L. cv. Malvazija istarska bijela, Food Technol Biotechnol. 46(1), 86-92.

Radeka, S., Lukić, I., Peršurić, Đ. (2012). Influence of Different Maceration Treatments on the Aroma Profile of Rosé and Red Wines from Croatian Aromatic cv. Muškat ruža porečki (Vitis vinifera L.) Food technology and biotechnology, 50(4), 442-453.

Ramey, D. Bertrand, A., Ough, C.S., Singleton, V.L. i Sanders, E. (1986). Effects of skin contact temperature on Chardonnay must and wine composition. Am. $J$. Enol. Vitic., 37(2), 99-106.

Rapp, A., Versini, G. (1995). Influence of nitrogen compounds in grapes on compounds of wine. In G. Charalambous (Ed.) Food flavour: Generation, analysis, and process influence (1659-1693). Elsevier Science BV.

Rapp, A., Mandery, H. (1986). Experientia, 42, 857.

Ribereau-Gayon P., Glories Y., Maujeau A., Dubordieu P. (2006). Handbook of Enology. The Chemistry of Wine Stabilization and Treatments. 2nd Ed Chichester: John Wiley and Sons.

Sáenz-Navajas, M.P., Avizcuri, J.M., Ballester, J., Fernández-Zurbano, P., Ferreira, V., Peyron, D., Valentin, D. (2015) Sensory-active compounds influencing wine experts' and consumers' perception of red wine intrinsic quality. LWT- Food Science and Technology, 60(1), 400-41. http://dx.doi.org/10.1016/j.lwt.2014.09.026

San-Juan, F., Ferreira, V., Cacho,J., Escudero, A. (2011). Quality and Aromatic Sensory Descriptors (Mainly Fresh and Dry Fruit Character) of Spanish Red Wines can be Predicted from their Aroma-Active Chemical Composition. Journal of Agricultural and Food Chemistry, 59 (14), 7916-7924. http://dx.doi.org/10.1021/jf1048657

Salaspuro, M. (2011). Acetaldehyde and gastric cancer. J. Dig. Dis., 12, 51 - 59 http://dx.doi.org/10.1111/j.1751-2980.2011.00480.x

Samappito S., Butkhup L. (2010). Effect of skin contact treatments on the aroma profile and chemical components of mulberry (Morus alba Linn.) wines. African Journal of Food Science, 4, 52-61.

Sanchez Palomo, E., Perez Coello, M.S, Diaz Maroto Hidalgo M.C, Gonzalez Vinas M.A, Cabezudo M.D. (2006). Contribution of free and glycosidicallybound volatile compounds to the aroma of muscat ,a petit grains" wines and effect of skin-contact treatment. Food Chemistry, 95(2), 279-289. http://dx.doi.org/10.1016/j.foodchem.2005.01.012

Schreier, P. (1979). Flavour composition of wines. CRC Critical Reviews in Food Science and Nutrition, 59-111.

Selli S., Canbas A., Cabaroglu T., Erten H., Lepoutre J.P., Günata Z. (2006) Effect of skin contact in the three and bound aroma components of the white wine of Vitis vinifera L. c.v. Narince. Food Control, 17, 75-82.

Selli, S., Canbas, A., Cabaroglu, T., Erten, H., Gunata, Z. (2006a). Aroma components of cv.Muscat of Bornova wines and influence of skin-contact treatment. Food Chemistry, 94(3), 319-326.

Sponholz, W. R. (1989). Der Wien 4.3. Fehlerhafte und unerwünschte Erscheinungen im Wein," in Chemie des Weines, eds. G. Würdig and R. Woller Stuttgart: Ulmer.

Swiegers, J., Bartowsky, E., Henschke, P., Pretorius, I. (2005). Yeast and bacterial modulation of wine aroma and flavour. Australian Journal of Grape and Wine Research, 11, 139-173._http://dx.doi.org/10.1111/j.17550238.2005.tb00285.x

Test S.L., Noble A.C., Schmidt J.O. (1986). Effect of pomace contact on Chardonnay musts and wines. American Journal of Enology and Viticulture, 37, $133-136$.

Usseglio-Tomasset L. (1995). Chimie oenologique. Paris: Tec and Doc Lavoisier. Waterhouse, A.L., Sacks, G.L., Jeffery, D.W. (2016). Understanding Wine Chemistry. Chichester: John Wiley and Sons. 